\title{
Effects of Kaolin Additives in Fly Ash on Sintering and Properties of Mullite Ceramics
}

\author{
Marta Valášková ${ }^{1, *(1)}$, Veronika Blahůšková ${ }^{1}$ and Jozef Vlček $^{1,2}$ \\ 1 Institute of Environmental Technology, CEET, VŠB-Technical University of Ostrava, 17. Listopadu 2172/15, \\ 70800 Ostrava-Poruba, Czech Republic; veronika.blahuskova@vsb.cz (V.B.); jozef.vlcek@vsb.cz (J.V.) \\ 2 Department of Thermal Engineering, Faculty of Materials Science and Technology, VŠB-Technical University \\ of Ostrava, 17. Listopadu 2172/45, 70800 Ostrava-Poruba, Czech Republic \\ * Correspondence: marta.valaskova@vsb.cz; Tel.: +420-597-327-308
}

Citation: Valášková, M.; Blahůšková, V.; Vlček, J. Effects of Kaolin Additives in Fly Ash on Sintering and Properties of Mullite Ceramics. Minerals 2021, 11, 887. https:// doi.org $/ 10.3390 / \min 11080887$

Academic Editor: Hegoi Manzano

Received: 13 July 2021

Accepted: 13 August 2021

Published: 17 August 2021

Publisher's Note: MDPI stays neutral with regard to jurisdictional claims in published maps and institutional affiliations.

Copyright: () 2021 by the authors. Licensee MDPI, Basel, Switzerland. This article is an open access article distributed under the terms and conditions of the Creative Commons Attribution (CC BY) license (https:// creativecommons.org/licenses/by/ $4.0 /)$.

\begin{abstract}
The effective utilization of fly ash (FA) as a raw material for ceramics production is performed on the FA-kaolin mixtures containing kaolins $10 \%$ by mass. The mixtures in comparison with FA and three raw kaolins were annealed to mullite ceramics at temperatures of 1000, 1100, 1200 and $1300{ }^{\circ} \mathrm{C}$. The main aims were to contribute to the discussion on the effect of impurity of $\mathrm{Na}, \mathrm{K}$ feldspars in kaolins and $\mathrm{Fe}_{2} \mathrm{O}_{3}$ in $\mathrm{FA}$ on sintering procedure, porous ceramics properties and mullite structural properties. The phases were characterized using X-ray diffraction and thermogravimetry DTA/TGA methods. Mercury intrusion porosimetry was used for characterization of porosity of ceramic samples. Results evidenced the influence of feldspars in kaolins and $\mathrm{Fe}_{2} \mathrm{O}_{3}$ in FA on the sintering temperatures and properties of mullite ceramics. The fully FA-based ceramic sintered at $1100{ }^{\circ} \mathrm{C}$ exhibited post-sintering properties of bulk density $2.1 \mathrm{~g} / \mathrm{cm}^{3}$; compressive strength $77.5 \mathrm{MPa}$; and porosity, $2 \%$ in comparison with the FA/kaolin-based ceramics properties of bulk density $2.2 \mathrm{~g} / \mathrm{cm}^{3}$; compressive strength, $60-65 \mathrm{MPa}$; and porosity from 9.3 to $16.4 \%$ influenced by $\mathrm{Na}, \mathrm{K}$-feldspars. The best structural and mechanical characteristics were found for the FAK3 sample, supported by the high content of kaolinite and orthoclase in the kaolin K3 additive. The FAK3 annealed at $1100{ }^{\circ} \mathrm{C}$ exhibited good compressive strength of $87.6 \mathrm{MPa}$ at a porosity of $10.6 \%$ and density of $2.24 \mathrm{~g} / \mathrm{cm}^{3}$ and annealed at $1300{ }^{\circ} \mathrm{C}$ the compressive strength of $41.3 \mathrm{MPa}$ at a porosity of $19.2 \%$ and density of $1.93 \mathrm{~g} / \mathrm{cm}^{3}$.
\end{abstract}

Keywords: fly ash; kaolins; mullite; microstructure; porosity

\section{Introduction}

Fly ash (FA) properties depend on the coal source, the method of combustion of power plants, storage, etc. For example, burning in pulverized-coal combustion boiler, the main oxide components of $\mathrm{FA}$ are $\mathrm{SiO}_{2}, \mathrm{Al}_{2} \mathrm{O}_{3}, \mathrm{Fe}_{2} \mathrm{O}_{3}, \mathrm{CaO}, \mathrm{MgO}, \mathrm{Na}_{2} \mathrm{O}$, and $\mathrm{K}_{2} \mathrm{O}$, and the crystalline phases are mullite $\left(3 \mathrm{Al}_{2} \mathrm{O}_{3} \cdot 2 \mathrm{SiO}_{2}\right)$ and quartz $\left(\mathrm{SiO}_{2}\right)$ [1]. FA and traditional ceramic raw materials have similar chemical and mineralogical compositions and therefore, make FA a promising ingredient in ceramics [2]. Architectural ceramics are typically prepared using a triaxial formulation of quartz (filler, 5-30 mass\%), clay (binder, 30-60 mass\%), and feldspar (fluxing agent, 15-40 mass\%) [3]. Quartz as a filler can be replaced by FA because of the proper filling properties. Effect of substitution of fly ash for quartz in triaxial kaolin-quartz-feldspar system demonstrated higher density and flexural strength $[4,5]$. However, FA as a high-temperature product cannot provide plasticity like a clay binder [6]. FA in the range of 5-40 mass \% replacing clay improved the bending strength, abrasion resistance, and hardness of porcelainized stoneware tiles but worsened the bending strength of the green compacts [7]. FA containing abundant alkali and alkaline earth metals can partially substitute for feldspar to promote melting, especially in the preparation of ceramic tiles [8,9]. Building mullite-based ceramics can be produced from the recycling of conventional coal combustion ash and clay in the initial mixture, acting as 
a binder and plasticizer, e.g., [10-12]. Kaolin in flay ash mixtures prevented the formation of open pores during mullite sintering [13]. Fly ash containing a large amount of reactive $\mathrm{SiO}_{2}$ and alumina $\mathrm{Al}_{2} \mathrm{O}_{3}$ produces mullite [14].

Much of the synthetic mullites of the approximate chemistry composition $3 \mathrm{Al}_{2} \mathrm{O}_{3}$ $2 \mathrm{SiO}_{2}$ were prepared by heating natural kaolin [15].

Kaolinite transforms at temperatures below $1000{ }^{\circ} \mathrm{C}$ during the removal of water and hydroxyl groups directly into mullite. Therefore, kaolinite is classified as a mullite precursor of Type I [14]. Kaolinite undergoes dehydroxylation at a temperature of around $550^{\circ} \mathrm{C}$ and its structure changes to disordered metakaolinite. Further heating to $900{ }^{\circ} \mathrm{C}$ resulted in the formation of primary mullite spinel, which subsequently crystallizes into mullite and cristobalite amorphous compounds by heating to a temperature range of $1000-1100{ }^{\circ} \mathrm{C}[16,17]$. Up to annealing temperatures of about $600{ }^{\circ} \mathrm{C}$ mullite gels lose virtually all molecular water which is weakly bound at the gel surface and in open pores, whereas the stronger, structurally bound hydroxyl groups are less affected. At temperatures above $700{ }^{\circ} \mathrm{C}$, the thermal energy is high enough for dehydroxylation and subsequent recombination of hydroxyl groups to water. Some of the newly formed water is trapped in nanopores giving rise to a relative increase in the water content. The diffusion of water molecules through the gel network at temperatures above $800{ }^{\circ} \mathrm{C}$ produced at $900{ }^{\circ} \mathrm{C}$ the mullite precursors almost water-free. Takei et al. [18] suggested three steps of the formation of mullite: (1) the dominant nucleation of mullite below $1000{ }^{\circ} \mathrm{C}$; (2) mullite nucleation and growth occur between 1000 and $1200{ }^{\circ} \mathrm{C}$; (3) mullite grain growth above about $1200{ }^{\circ} \mathrm{C}$. The formation of three kinds of mullite gels was classified according to DTA exotherms [19]. The first exotherm at about $980^{\circ} \mathrm{C}$ was assigned to the monophasic mullite; the second exotherm at about $1250{ }^{\circ} \mathrm{C}$ to the diphasic gel of mullite and the Al-Si spinel phase and the third exotherm at about $1300{ }^{\circ} \mathrm{C}$ to mullite. During the transformation from metakaolinite to mullite, the process undergoes several poorly-ordered thermal phases. The middle phases occur at around $925^{\circ} \mathrm{C}$ and have been referred to as the "defect spinel type phase which is believed to either be Al-Si-spinel $\left(\mathrm{Al}_{2} \mathrm{O}_{3} \cdot \mathrm{SiO}_{2}\right)$ or $\mathrm{Al}$ spinel $\left(\gamma\right.$-alumina, $\left.\gamma-\mathrm{Al}_{2} \mathrm{O}_{3}\right)$ ". There are reports of cubic mullite crystallizing poorly at this temperature. The well-crystallized mullite was observed at around $1200{ }^{\circ} \mathrm{C}$ [20]. The primary mullite dissolves at a temperature above $1300{ }^{\circ} \mathrm{C}$ and the secondary mullite forms by a solution-precipitation process [21]. The crystal structure of mullite consists of chains of edge-sharing $\mathrm{AlO}_{6}$ octahedra interconnected by tetrahedral $\mathrm{AlO}_{4}$ or $\mathrm{SiO}_{4}$ double chains and oxygen vacancies compensated the non-stoichiometry [22]. The chemical composition of mullite can be derived from its lattice constant $a$ according to the linear relationship to the molar content of $\mathrm{Al}_{2} \mathrm{O}_{3}$. The previous study reported that mullite lattice parameter $b$ increases with the $\mathrm{Fe}_{2} \mathrm{O}_{3}$ content due to $\mathrm{Fe}^{\mathrm{III}}$ substituting for $\mathrm{Al}^{\mathrm{III}}$. The expansion of cell edges $b$ stronger than $a$ was attributed to a volume increase in the octahedra due to iron incorporation [23].

The presence of chemical components $\mathrm{K}_{2} \mathrm{O}, \mathrm{Na}_{2} \mathrm{O}, \mathrm{CaO}$, and $\mathrm{Fe}_{2} \mathrm{O}_{3}$ are related to minor constituents in kaolins and in FA. The components act as fusing agents on reactivity of silica and alumina, support decrease in firing temperature, high shrinkage and low porosity $[17,24]$. The alkali metal elements determined in kaolin by $\mathrm{X}$-ray fluorescence analysis are mostly bound in the structures of micas and feldspars. Several works have provided evidence of potassium in feldspars and $\mathrm{KNO}_{3}, \mathrm{~K}_{2} \mathrm{SO}_{4}$ and $\mathrm{KF}$ additives promoting at $1100{ }^{\circ} \mathrm{C}$ crystallization of mullite at the expense of cristobalite [25-27]. Similarly, at $1050{ }^{\circ} \mathrm{C}$ potassium diffusion ions from muscovite supported crystallization of mullite in kaolinite-muscovite mixtures [28].

Most of the studies about the effect of sintering aids on the sintering and the characterization of mullite were carried out with the specimens produced from oxide powder mixtures or fly ash. However, there are few reports about the effect of sintering aids in kaolin-based mullite ceramics. Hou et al. [29] found, that the addition of $\mathrm{MgO}$ and $\mathrm{MoO}_{3}$ $(10 \mathrm{~mol} \%)$ in kaolin promoted the formation of the secondary mullite, $\mathrm{MoO}_{3}$ supported an increase in porosity and flexural strength, while $\mathrm{TiO}_{2}$ retarded mullite transformation. 
This paper focuses on the use of coal ash (FA) and raw kaolins additive in the production of mullite ceramics. FA and kaolins are classified as mullite ceramic precursors. FA as a high-temperature product cannot provide plasticity, while clays in ceramic mixtures act as a binder and plasticizer. The objectives of the study are focused on the characterization of ceramics prepared from the three mullite precursors: (1) FA, (2) raw kaolins, and (3) FA-kaolin additive $10 \%$ by mass and annealed at temperatures of 1000, 1100 1200 and $1300{ }^{\circ} \mathrm{C}$, which, according to the literature, were assigned to the formation of the monophasic mullite, the diphasic gel of mullite and the Al-Si spinel phase and the mullite.

The solution is focused on the effect of impurities in kaolins and fly ash on the formation of phases, porosity and strength of ceramics and crystal chemical properties of mullite. The main aim was to document and explain the effect of impurity of $\mathrm{Na}, \mathrm{K}$ and Fe bounded in $\mathrm{Na}, \mathrm{K}$ - and $\mathrm{K}$-feldspars in kaolins and $\mathrm{Fe}_{2} \mathrm{O}_{3}$ in FA on sintering procedure, porous ceramics properties and mullite structure crystallizing at 1000 and $1300{ }^{\circ} \mathrm{C}$.

\section{Experimental Part}

\subsection{Materials}

Fly ash (the sample marked FA) was obtained from the combustion of black coal captured on an electrostatic precipitator in the powder station (Czech Republic). The three kaolin samples from the Czech kaolin deposits were purchased from the LB Minerals, Ltd., Horní Bříza, Czech Republic. Two samples originating from the kaolin Pilsen Basin were marked K1 and K2 and one sample from the Karlovy Vary region was marked K3. These kaolins generally contain kaolinite in an average amount of $75 \%$ by mass and the original minerals, in particular quartz, muscovite/illite and feldspars from their original rocks $[30,31]$.

\subsection{Sample Preparation}

The kaolin samples $\mathrm{K} 1, \mathrm{~K} 2$ and $\mathrm{K} 3$ and FA were prepared in the FA:K mass ratio of 9:1 to the mixtures designated FA/K1, FA/K2 and FA/K3. Each mixture was homogenized for $1 \mathrm{~h}$ in bottle at the rotate speed of $40 \mathrm{r} \cdot \mathrm{min}^{-1}$ (Heidolph Reax overhead shaker, REAX 20/4, Merck KGaA, Darmstadt, Germany) and then mixed in the agate planetary ball mill (FRITSCH-Pulverisette 6) for $15 \mathrm{~min}$ at the rotate speed of $300 \mathrm{r} \cdot \mathrm{min}^{-1}$. Samples for sintering were prepared into a slurry with the addition of $20 \%$ by mass of distilled water. The slurry was manually pressed into cubic voids $(20 \mathrm{~mm} \times 20 \mathrm{~mm} \times 20 \mathrm{~mm})$ of metal molds. The samples in molds were left for $24 \mathrm{~h}$ at room temperature and then dried at $110^{\circ} \mathrm{C}$ for $5 \mathrm{~h}$ in an oven. Dry samples were taken out of the molds and sintered in an electrical laboratory furnace LH15/13 at the heating ramp $12{ }^{\circ} \mathrm{C} / \mathrm{min}$ to the desired temperature of $1000,1100,1200,1300{ }^{\circ} \mathrm{C}$ and maintained at this temperature for $2 \mathrm{~h}$. The sintering temperature of the ceramic sample is indicated at the end of the designation (e.g., FA/K1-1000).

\subsection{Methods}

Elemental analysis of metal oxide concentrations was performed using a SPECTRO XEPOS energy dispersive X-ray fluorescence (ED-XRF) spectrometer (Spectro Analytical Instruments, Kleve, Germany). Mineral phases were characterized by X-ray powder diffraction (XRD) using XRD patterns (Rigaku SmartLab diffractometer, Rigaku Corporation, Tokyo, Japan) under $\mathrm{CoK}_{\alpha}$ radiation at $40 \mathrm{kV}$ and $40 \mathrm{~mA}$, at $15 \mathrm{r} \cdot \mathrm{min}^{-1}$, a step size of $0.01^{\circ}$. The thermal analysis of kaolins powders and FA/K mixtures dried at $110^{\circ} \mathrm{C}$ was performed on the Simultaneous DTA/TGA SDT 650 system (TA Instruments, New Castle, DE, USA) in an air dynamic atmosphere with a flow rate of $0.1 \mathrm{~L} \mathrm{~min}^{-1}$ at a heating rate of $10{ }^{\circ} \mathrm{C} \mathrm{min}^{-1}$ over the range $25-1400{ }^{\circ} \mathrm{C}$. The porosity of the ceramic samples was measured using a mercury intrusion porosimeter AutoPore IV 9500 (Micromeritics Instrument Corporation, Norcross, GA, USA). The compressive strength (CS) parameters of ceramic samples were measured using the SERVO-PLUS EVOLUTION hydraulic concrete compression machine 2400 kN (MATEST S.p.A., Treviolo (BG), Italy). 


\section{Results and Discussion}

\subsection{Fly Ash and Kaolin's Chemistry and Phases}

The FA has already undergone a high-temperature process in which organic materials have either been burned off or were converted. XRF analysis (Table 1) indicated that FA according to ASTM C618 is a Class F ash [32]. The XRD pattern of FA confirms the presence of the two major crystalline phases: mullite $\left(\mathrm{Al}_{4.64} \mathrm{Si}_{1.36} \mathrm{O}_{9.68}\right.$, JCPDS card no. 00-079-1453), quartz $\left(\mathrm{SiO}_{2}\right.$, JCPDS card no. 01-089-1961) and noncrystalline phases observed as an amorphous halo. Other phases were anorthite $\left(\mathrm{Ca}\left(\mathrm{Al}_{2} \mathrm{Si}_{2} \mathrm{O}_{8}\right)\right.$, JCPDS card no. 00-076-0948) and hematite $\left(\mathrm{Fe}_{2} \mathrm{O}_{3}\right.$, JCPDS card no. 00-089-0596). Kaolin samples $\mathrm{K} 1, \mathrm{~K} 2$ and $\mathrm{K} 3$ contain kaolinite (JCPDS card no. 00-058-2005), muscovite (JCPDS card no. 00-084-1306), and quartz (JCPDS card no. 00-089-1961). Feldspars were identified in all the three kaolins as orthoclase $\left(\mathrm{K}_{0.93} \mathrm{Na}_{0.06}\right)\left(\mathrm{Al}_{0.97} \mathrm{Si}_{3.03} \mathrm{O}_{8}\right)$ (JCPDS card no. 01-076-0824) in $\mathrm{K} 1$ and $\mathrm{K} 2$ (marked as $\mathrm{K}, \mathrm{Na}$ in Table 2) and ( $\mathrm{KAlSi}_{3} \mathrm{O}_{8}$, JCPDS card no. 00-075-1592) in $\mathrm{K} 3$ (marked as $\mathrm{K}$ in Table 2).

Table 1. XRF of metal oxides (mass\%) of the fly ash (FA) and kaolin samples (K).

\begin{tabular}{cccccccccccc}
\hline Sample & $\mathbf{S i O}_{\mathbf{2}}$ & $\mathrm{TiO}_{\mathbf{2}}$ & $\mathbf{A l}_{\mathbf{2}} \mathbf{O}_{\mathbf{3}}$ & $\mathbf{F e}_{\mathbf{2}} \mathbf{O}_{\mathbf{3}}$ & $\mathbf{C a O}$ & $\mathbf{M g O}$ & $\mathbf{K}_{\mathbf{2}} \mathbf{O}$ & $\mathbf{N a}_{\mathbf{2}} \mathbf{O}$ & $\mathbf{S O}_{\mathbf{3}}$ & $\mathbf{P}_{\mathbf{2}} \mathbf{O}_{\mathbf{5}}$ & L.O.I. $^{\mathbf{1}}$ \\
\hline $\mathrm{FA}$ & 44.83 & 1.26 & 23.93 & 7.16 & 2.83 & 1.81 & 3.03 & 0.68 & 0.72 & 0.69 & 2.36 \\
$\mathrm{~K} 1$ & 49.52 & 1.01 & 30.57 & 0.76 & 0.23 & 0.23 & 1.48 & 3.76 & 0.07 & 0.07 & 11.48 \\
$\mathrm{~K} 2$ & 49.63 & 0.75 & 29.70 & 0.71 & 0.26 & 0.28 & 2.36 & 3.96 & 0.08 & 0.07 & 11.11 \\
$\mathrm{~K} 3$ & 48.51 & 0.87 & 34.03 & 0.80 & 0.30 & 0.35 & 2.74 & 0.00 & 0.09 & 0.07 & 10.93 \\
\hline
\end{tabular}

${ }^{1}$ L.O.I. (Loss On Ignition) at $1000{ }^{\circ} \mathrm{C}$.

Table 2. Crystalline phases identified (+) and absent (-) in natural and annealed kaolin samples.

\begin{tabular}{|c|c|c|c|c|c|}
\hline Sample & Kaolinite & Quartz & Muscovite & Feldspar $^{1}$ & Mullite $^{2}$ \\
\hline K1 & + & + & + & $\mathrm{K}, \mathrm{Na}$ & - \\
\hline $\mathrm{K} 2$ & + & + & + & $\mathrm{K}, \mathrm{Na}$ & - \\
\hline K3 & + & + & + & K & - \\
\hline K1-1000 & - & + & + & $\mathrm{Na}, \mathrm{K}$ & $\mathrm{Mu}^{1}$ \\
\hline K1-1100 & - & + & - & $\mathrm{Na}, \mathrm{K}$ & $\mathrm{Mu}^{1}$ \\
\hline K1-1200 & - & + & - & $\mathrm{Na}, \mathrm{K}$ & $\mathrm{Mu}^{2}$ \\
\hline K1-1300 & - & + & - & $\mathrm{Na}, \mathrm{K}$ & $\mathrm{Mu}^{2}$ \\
\hline K2-1000 & - & + & + & $\mathrm{Na}, \mathrm{K}$ & $\mathrm{Mu}^{1}$ \\
\hline K2-1100 & - & + & - & $\mathrm{Na}, \mathrm{K}$ & $\mathrm{Mu}^{1}$ \\
\hline K2-1200 & - & + & - & $\mathrm{Na}, \mathrm{K}$ & $\mathrm{Mu}^{2}$ \\
\hline K2-1300 & - & + & - & $\mathrm{Na}, \mathrm{K}$ & $\mathrm{Mu}^{2}$ \\
\hline K3-1000 & - & + & - & K & $\mathrm{Mu}^{3}$ \\
\hline K3-1100 & - & + & - & K & $\mathrm{Mu}^{3}$ \\
\hline K3-1200 & - & + & - & $\mathrm{K}$ & $\mathrm{Mu}^{3}$ \\
\hline K3-1300 & - & + & - & K & $\mathrm{Mu}^{3}$ \\
\hline
\end{tabular}
$\left(\mathrm{Na}_{0.75} \mathrm{~K}_{0.25}\right) \mathrm{AlSi}_{3} \mathrm{O}_{8} .{ }^{2} \mathrm{Mu}^{1}=$ mullite $\mathrm{Al}_{4.64} \mathrm{Si}_{1.36} \mathrm{O}_{9.68} ; \mathrm{Mu}^{2}=$ mullite $\mathrm{Al}_{6} \mathrm{Si}_{2} \mathrm{O}_{13} ; \mathrm{Mu}^{3}=$ mullite $\mathrm{Al}_{4.52} \mathrm{Si}_{1.48} \mathrm{O}_{9.74}$.

Kaolin samples K1 and K2 showed very similar elemental oxide composition and different from kaolin $\mathrm{K} 3$, especially in the quantity of $\mathrm{Na}_{2} \mathrm{O}$ (Table 1). XRD semi-quantitative analysis of crystalline phases in kaolin samples was performed using the normalized RIR (Reference Intensity Ratio) method [33]. Kaolin sample K3 contained the highest amount ( $85.5 \%$ by mass) of kaolinite and low amount $(2.8 \%)$ of quartz, in comparison with kaolin samples $\mathrm{K} 1$ and $\mathrm{K} 2$, composed of kaolinite $77 \%$ and $81 \%$, respectively, and quartz $13.2 \%$ and $5.3 \%$, respectively. All three kaolin samples contained muscovite from $6.0 \%$ in $\mathrm{K} 2$ to $8.5 \%$ in $\mathrm{K} 1$ and feldspar (orthoclase) $1.3 \%$ in $\mathrm{K} 1,7.7 \%$ in $\mathrm{K} 2$ and $5.0 \%$ in K3 (Figure 1). 


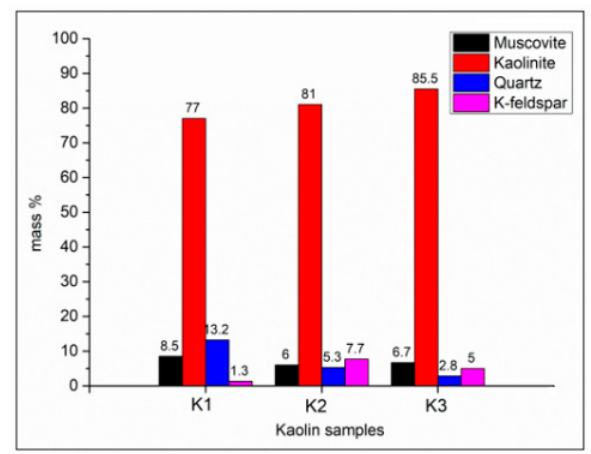

Figure 1. Semi-quantitative composition of crystalline phases in kaolin samples.

\subsection{Annealing Samples at $1000,1100,1200$ and $1300^{\circ} \mathrm{C}$}

In 1958, Brindley and Nakahira [15] suggested a new concept of the transformation sequence of kaolinite to mullite at temperatures $500^{\circ} \mathrm{C}$ (Equation (1)), $925^{\circ} \mathrm{C}$ (Equation (2)), $1100{ }^{\circ} \mathrm{C}$ (Equation (3)) and above $1500{ }^{\circ} \mathrm{C}$ (Equation (4)) as follows:

$$
\begin{gathered}
\mathrm{Al}_{2} \mathrm{O}_{3} 2 \mathrm{SiO}_{2} 2 \mathrm{H}_{2} \mathrm{O} \rightarrow \mathrm{Al}_{2} \mathrm{O}_{3} 2 \mathrm{SiO}_{2}+2 \mathrm{H}_{2} \mathrm{O} \text { (metakaolinite) } \\
2\left(\mathrm{Al}_{2} \mathrm{O}_{3} 2 \mathrm{SiO}_{2}\right) \rightarrow 2 \mathrm{Al}_{2} \mathrm{O}_{3} 3 \mathrm{SiO}_{2}+\mathrm{SiO}_{2} \text { (silicon spinel) } \\
2 \mathrm{Al}_{2} \mathrm{O}_{3} 3 \mathrm{SiO}_{2} \rightarrow 2\left(\mathrm{Al}_{2} \mathrm{O}_{3} \mathrm{SiO}_{2}\right)+\mathrm{SiO}_{2}(1: 1 \text { mullite-type phase) } \\
3\left(\mathrm{Al}_{2} \mathrm{O}_{3} \mathrm{SiO}_{2}\right) \rightarrow 3 \mathrm{Al}_{2} \mathrm{O}_{3} 2 \mathrm{SiO}_{2}+\mathrm{SiO}_{2} \text { (3:2 mullite) }
\end{gathered}
$$

Kaolinites in kaolins $\mathrm{K} 1$ and $\mathrm{K} 2$ annealed at temperature 1000 and $1100{ }^{\circ} \mathrm{C}$ were transformed to mullite $\mathrm{Al}_{4.64} \mathrm{Si}_{1.36} \mathrm{O}_{9.68}$ (JCPDS card no. 00-079-1453), (marked as $\mathrm{Mu}^{1}$ in Table 2), and at temperature of 1200 and $1300{ }^{\circ} \mathrm{C}$ to mullite $\mathrm{Al}_{6} \mathrm{Si}_{2} \mathrm{O}_{13}$ (JCPDS card no. 00-015-0776), (marked as $\mathrm{Mu}^{2}$ in Table 2). Kaolinite in kaolin $\mathrm{K} 3$ was transformed at temperatures $1000,1100,1200$ and $1300{ }^{\circ} \mathrm{C}$ to mullite $\mathrm{Al}_{4.52} \mathrm{Si}_{1.48} \mathrm{O}_{9.74}$ (JCPDS card no. 00-079-1457), (marked as $\mathrm{Mu}^{3}$ in Table 2).

Orthoclase $\left(\mathrm{K}_{0.93} \mathrm{Na}_{0.06}\right)\left(\mathrm{Al}_{0.97} \mathrm{Si}_{3.03} \mathrm{O}_{8}\right)$ in $\mathrm{K} 1$ and $\mathrm{K} 2$ changed at $1000{ }^{\circ} \mathrm{C}$ to anorthoclase $\left(\mathrm{Na}_{0.75} \mathrm{~K}_{0.25}\right) \mathrm{AlSi}_{3} \mathrm{O}_{8}$ (JCPDS card no. 00-075-1632), (marked as $\mathrm{Na}, \mathrm{K}$ in Table 2). Orthoclase $\mathrm{KAlSi}_{3} \mathrm{O}_{8}$ in $\mathrm{K} 3$ at annealing temperatures used did not change.

The XRD patterns of kaolin samples K1, K2, K3 and FA (Figure 2) demonstrate the formation of primary mullites annealed at temperatures of $1000^{\circ} \mathrm{C}$ (Figure 2a) and secondary mullites annealed at temperature $1300^{\circ} \mathrm{C}$ (Figure $2 \mathrm{~b}$ ).

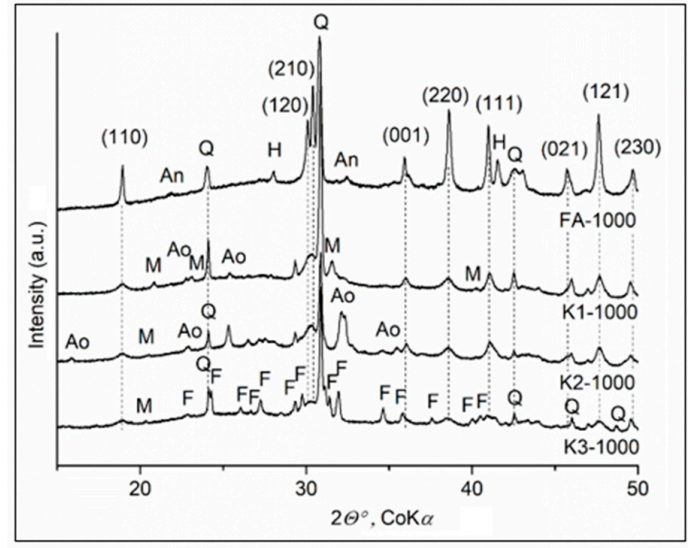

(a)

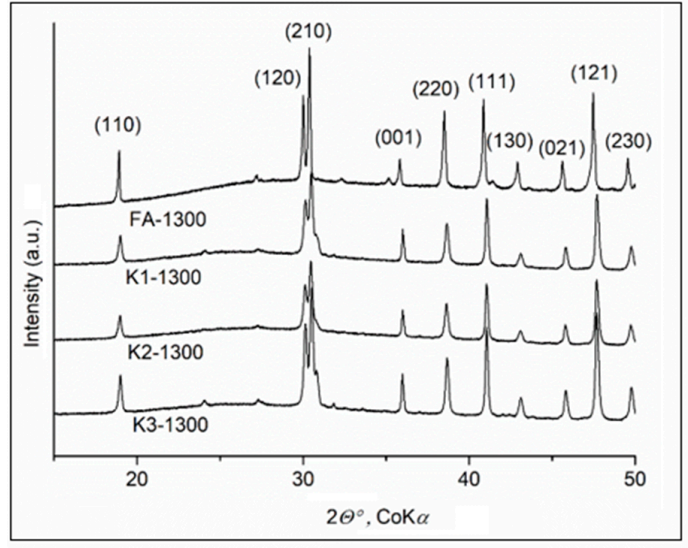

(b)

Figure 2. XRD patterns of kaolin samples $\mathrm{K} 1, \mathrm{~K} 2, \mathrm{~K} 3$ and FA annealed at temperatures: (a) $1000{ }^{\circ} \mathrm{C}$ and (b) $1300{ }^{\circ} \mathrm{C}$. $\mathrm{M}$-muscovite, Q-quartz, F-orthoclase, Ao-anorthoclase, An—anorthite, H—hematite, (hkl)—mullite. 
The main crystalline phases in all annealed FA/K samples (Table 3) were mullite (JCPDS card no. 00-079-1453), quartz (JCPDS card no. 01-083-0539), anorthite $\mathrm{Ca}\left(\mathrm{Al}_{2} \mathrm{Si}_{2} \mathrm{O}_{8}\right)$ (JCPDS card no. 01-076-0948) and hematite, $\mathrm{Fe}_{2} \mathrm{O}_{3}$ (JCPDS card no. 00-089-0596). Spinel $\mathrm{Mg}(\mathrm{Al}, \mathrm{Fe})_{2} \mathrm{O}_{4}$ (JCPDS card no. 00-021-0540) was identified at temperatures 1100 and $1200{ }^{\circ} \mathrm{C}$, and hematite transformed at $1300{ }^{\circ} \mathrm{C}$ to magnetite (JCPDS card no. 00-0861347), when the temperature exceeds $1250^{\circ} \mathrm{C}$ [34]. The phases identified are in Table 3 and on XRD patterns (Figure 3) of FA FA/K1 (Figure 3a) and FA/K3 (Figure 3b) samples.

Table 3. Crystalline phases identified (+) and absent (-) in annealed FA and FA/K samples.

\begin{tabular}{|c|c|c|c|c|c|c|}
\hline Sample & Mullite & Quartz & Anorthite & Hematite & Spinel & Magnetite \\
\hline FA-1000 & + & + & + & + & - & - \\
\hline FA-1100 & + & + & + & + & - & - \\
\hline FA-1200 & + & + & + & + & - & - \\
\hline FA-1300 & + & + & + & + & - & + \\
\hline FA/K1-1000 & + & + & + & + & - & - \\
\hline FA/K1-1100 & + & + & + & + & + & - \\
\hline FA/K1-1200 & + & + & + & + & + & - \\
\hline FA/K1-1300 & + & - & + & - & - & + \\
\hline $\mathrm{FA} / \mathrm{K} 2-1000$ & + & + & + & + & - & - \\
\hline FA/K2-1100 & + & + & + & + & + & - \\
\hline $\mathrm{FA} / \mathrm{K} 2-1200$ & + & + & + & + & + & - \\
\hline FA/K2-1300 & + & - & + & - & - & + \\
\hline FA/K3-1000 & + & + & + & + & - & - \\
\hline FA/K3-1100 & + & + & + & + & + & - \\
\hline FA/K3-1200 & + & + & + & + & + & - \\
\hline FA/K3-1300 & + & - & + & - & - & + \\
\hline
\end{tabular}

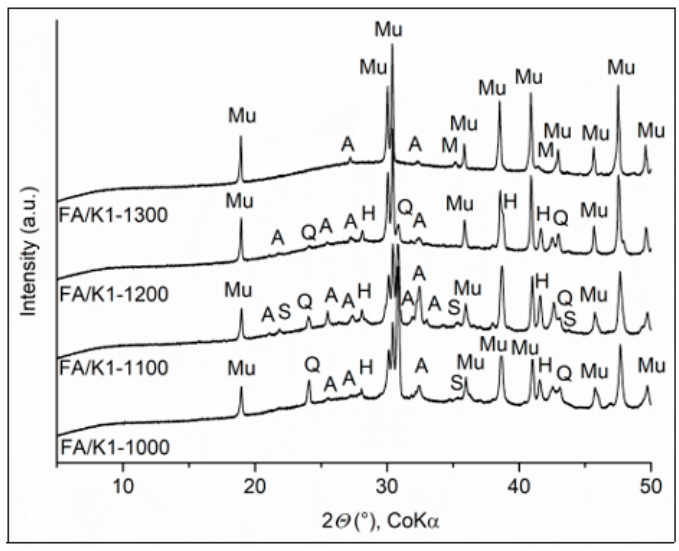

(a)

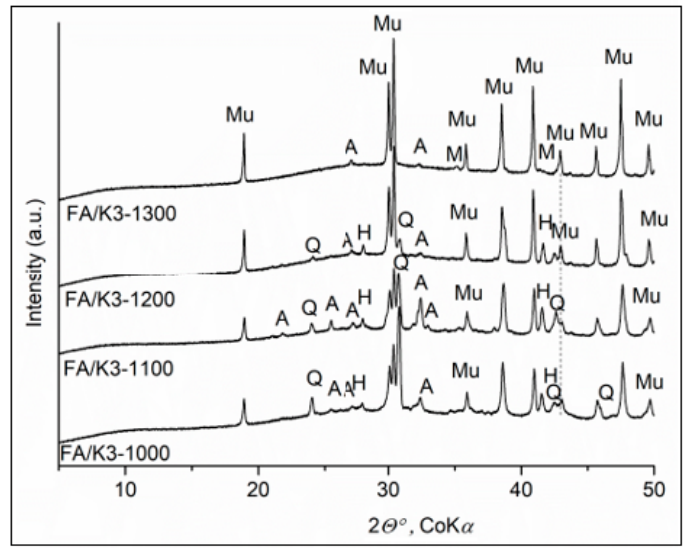

(b)

Figure 3. XRD patterns of: (a) FA/K1 and (b) FA/K3 at annealing temperatures from 1000 to $1300{ }^{\circ} \mathrm{C}$. Mu-mullite, $\mathrm{Q}$-quartz, A—anorthite, $\mathrm{H}$-hematite, S—spinel and $\mathrm{M}$-magnetite.

\subsection{Shrinkage, Porosity and Compressive Strength}

The base shrinkage (BS) ratio of the cubes from the size of the length of $2.0 \mathrm{~cm} \times$ $2.0 \mathrm{~cm} \times 2.0 \mathrm{~cm}$ after annealing at $1000,1100,1200$ and $1300{ }^{\circ} \mathrm{C}$ was calculated according to Equation (5) [35]:

$$
B S=(\operatorname{Los}-L d) / \operatorname{Los} \times 100 \%
$$

$B S$ is the shrinkage after annealing, Los is the original length, and $L d$ is the length after firing. BS values in Table 4 are an averaged length changes of the five cubes of each sample. 
Table 4. Shrinkage, Porous Values and Compressive Strength of Annealed Samples.

\begin{tabular}{|c|c|c|c|c|c|c|}
\hline Samples & $\begin{array}{l}B S \\
\%\end{array}$ & $\begin{array}{c}P \\
(\%)\end{array}$ & $\begin{array}{l}\text { MDP } \\
(\mu \mathrm{m})\end{array}$ & $\begin{array}{c}\text { TPA } \\
\left(\mathrm{m}^{2} / \mathrm{g}\right)\end{array}$ & $\begin{array}{c}\mathrm{AD} \\
\mathrm{g} / \mathrm{m}^{3}\end{array}$ & $\begin{array}{c}\mathrm{CS} \\
(\mathrm{MPa})\end{array}$ \\
\hline FA-1000 & $16.7 \pm 0.1$ & 24.4 & 0.86 & 3.28 & 2.33 & $108.4 \pm 2.1$ \\
\hline FA-1100 & $29.6 \pm 0.6$ & 1.9 & 1.83 & 1.21 & 2.11 & $100.1 \pm 2.2$ \\
\hline FA-1200 & $-2.5 \pm 2.0$ & 26.0 & 9.97 & 9.32 & 2.06 & $77.5 \pm 1.3$ \\
\hline FA-1300 & $-74.5 \pm 5.5$ & 29.2 & 0.02 & 53.90 & 1.82 & $9.3 \pm 0.6$ \\
\hline FA/K1-1000 & $13.4 \pm 2.3$ & 32.2 & 1.15 & 3.23 & 2.39 & $37.1 \pm 0.3$ \\
\hline $\mathrm{FA} / \mathrm{K} 1-1100$ & $31.8 \pm 1.1$ & 9.3 & 0.89 & 1.94 & 2.08 & $65.2 \pm 1.9$ \\
\hline FAK1-1200 & $9.0 \pm 1.2$ & 20.4 & 8.57 & 5.40 & 2.18 & $74.4 \pm 2.8$ \\
\hline $\mathrm{FA} / \mathrm{K} 1-1300$ & $-21.6 \pm 1.8$ & 28.1 & 24.14 & 18.63 & 1.97 & $26.6 \pm 1.9$ \\
\hline FA/K2-1000 & $10.7 \pm 2.8$ & 33.5 & 1.35 & 3.05 & 2.32 & $41.4 \pm 0.8$ \\
\hline $\mathrm{FA} / \mathrm{K} 2-1100$ & $29.7 \pm 0.7$ & 16.4 & 1.38 & 1.66 & 2.21 & $60.1 \pm 3.7$ \\
\hline FAK2-1200 & $8.8 \pm 1.5$ & 17.5 & 8.20 & 4.50 & 2.05 & $61.2 \pm 1.7$ \\
\hline FA/K2-1300 & $-21.9 \pm 3.2$ & 25.7 & 0.13 & 34.20 & 1.88 & $31.1 \pm 0.3$ \\
\hline FA/K3-1000 & $11.1 \pm 2.8$ & 29.4 & 0.85 & 4.00 & 2.24 & $66.7 \pm 1.4$ \\
\hline FA/K3-1100 & $29.2 \pm 0.2$ & 10.6 & 0.72 & 1.94 & 2.24 & $87.6 \pm 1.7$ \\
\hline FAK3-1200 & $14.7 \pm 1.1$ & 11.0 & 0.15 & 4.28 & 1.96 & $65.8 \pm 0.7$ \\
\hline $\mathrm{FA} / \mathrm{K} 3-1300$ & $-4.4 \pm 0.3$ & 19.2 & 24.5 & 10.23 & 1.93 & $41.3 \pm 1.4$ \\
\hline
\end{tabular}

BS-Base Shrinkage Ratio; P-Porosity; MPD—Median Pore Diameter (volume); TPA—Total Pores Area; AD—Apparent Density at 226.7 MPa; CS—Compressive Strength.

\subsection{Effect of Feldspars in Kaolins on Thermal Decomposition}

Thermal changes during the progress of sintering were monitored from 25 to $1400{ }^{\circ} \mathrm{C}$ (Figure 4). DTA curve of FA revealed the two endotherms maxima at about 1288 and $1310{ }^{\circ} \mathrm{C}$. These maxima of FA/K1, FA/K2 and FA/K3 were at about 1165 and $1250{ }^{\circ} \mathrm{C}$. The exothermic peaks maxima at all samples was at $1335^{\circ} \mathrm{C}$ (Figure $4 \mathrm{a}$ ). The endotherm was assigned to the melting and maximum to the crystallization of mullite [27]. The mass loss at $1100{ }^{\circ} \mathrm{C}$ in FA and kaolin $\mathrm{K} 3$ was similar (3.0\%) in comparison with $\mathrm{K} 1$ and $\mathrm{K} 2$ (5.2 and 6.5\%), (Figure $4 \mathrm{~b}$ ). The effect of individual basic oxides, $\mathrm{CaO}, \mathrm{Fe}_{2} \mathrm{O}_{3}, \mathrm{Na}_{2} \mathrm{O}$ and $\mathrm{K}_{2} \mathrm{O}$ and the ratio of Base/ Acid, $\mathrm{SiO}_{2} / \mathrm{AlO}_{3}$ and $\mathrm{CaO} / \mathrm{Fe}_{2} \mathrm{O}_{3}$ on ash fusibility has been widely discussed [36]. Generally, the melting temperature in $\mathrm{FA}$ was increased by $\mathrm{SiO}_{2}$ and $\mathrm{Al}_{2} \mathrm{O}_{3}$. The basic oxides $\mathrm{K}_{2} \mathrm{O}$ or $\mathrm{Na}_{2} \mathrm{O}$ and feldspar minerals containing $\mathrm{K}$ or $\mathrm{Na}$ form lower melting point and improve fusibility. Intensity of the feldspar peaks on XRD pattern decreased slightly due to decrease in crystallinity when the temperature was higher than $1000{ }^{\circ} \mathrm{C}$ and finally disappeared at $1300^{\circ} \mathrm{C}$, similarly, as it has been observed in [37]. The mixtures of kaolins $\mathrm{K} 1$ and $\mathrm{K} 2$ and FA produced on the TG curves in comparison with FA about twice the mass loss of FA/K1 and more than three times greater mass loss of FA/K2.

The reaction of $\mathrm{CaO}$ with the silica led to the formation of aluminosilicates and limited formation of a liquid phase during sintering [38]. At a temperature of $1100^{\circ} \mathrm{C}$, intensity of peaks of anorthite increased (Figure 2a) due to the reaction of $\mathrm{CaO}$ from FA with a decomposition product of kaolinite, according to the reaction shown in Equation (6):

$$
\mathrm{Al}_{2} \mathrm{O}_{3} \cdot 2 \mathrm{SiO}_{2} \text { (Metakaolinite) }+\mathrm{CaO} \rightarrow \mathrm{CaO} \cdot \mathrm{Al}_{2} \mathrm{O}_{3} \cdot 2 \mathrm{SiO}_{2} \text { (Anorthite) }
$$

The fact that all the natural feldspars can be expressed in terms of the three end members, orthoclase $(\mathrm{K})$, albite $(\mathrm{Na})$ and anorthite $(\mathrm{Ca})$ was declared long ago, e.g., [37]. Moreover, as there is very little solid solution between orthoclase and anorthite it is convenient to consider the chemical relationships of the feldspar group in terms of two major series, the alkali feldspars and the plagioclases. Structural change of feldspar in kaolin samples $\mathrm{K} 1$ and $\mathrm{K} 2$ at $1000{ }^{\circ} \mathrm{C}$ (Table 2) observed on the intensive endotherms on the TG curves and mass loss probably supported reactions with $\mathrm{CaO}$ in FA/K1 and FA/K2 (Figure 2). 


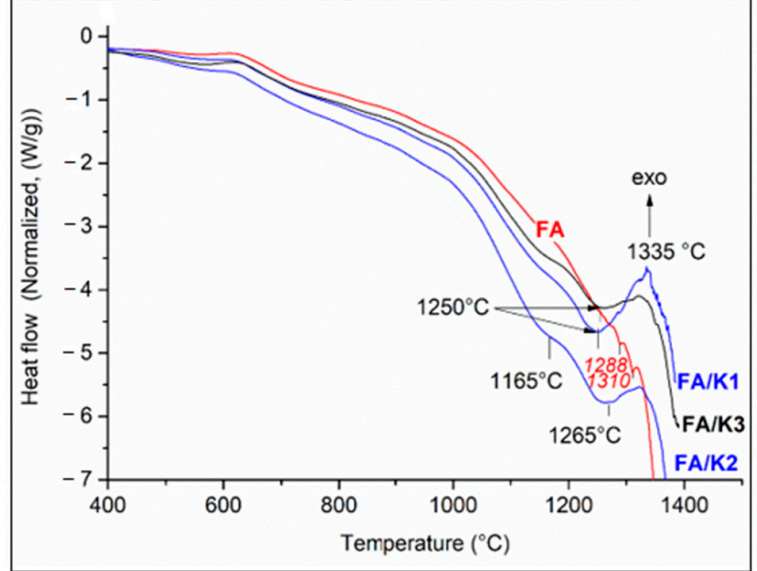

(a)

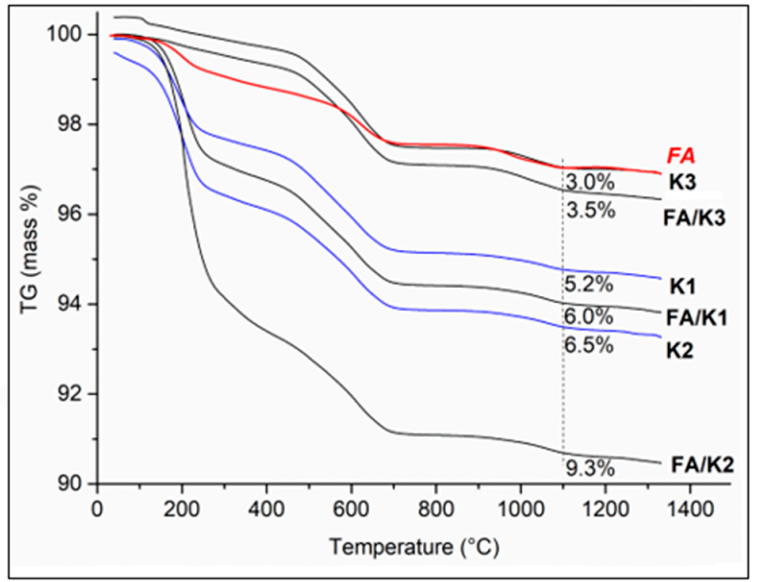

(b)

Figure 4. Decomposition of samples on the thermal curves: (a) DTA and (b) TG.

\subsection{Effect of $\mathrm{Fe}_{2} \mathrm{O}_{3}$ on Mullite Structure}

The ash fusion system in the pseudo-ternary system $\mathrm{Al}_{2} \mathrm{O}_{3}-\mathrm{SiO}_{2}-\mathrm{Base}(\mathrm{FeO}+\mathrm{CaO}$ $+\mathrm{K}_{2} \mathrm{O}$ ) [39] allowed to determine about 5 mass $\%$ solid solution limit of $\mathrm{Fe}_{2} \mathrm{O}_{3}$ in mullite structure sintered at $1300{ }^{\circ} \mathrm{C}$ [24]. Considering the presence of $\mathrm{Fe}_{2} \mathrm{O}_{3}$ in FA and kaolins (Table 1) as well as hematite (Table 3), substitution of $\mathrm{Fe}^{3+}$ for $\mathrm{Al}^{3+}$ in the mullite structure can be assumed. Lattice parameters of mullites were obtained from the Rietveld analysis of the XRD patterns. The expansion of lattice parameters in primary mullites at $1000{ }^{\circ} \mathrm{C}$ and secondary mullites at $1300^{\circ} \mathrm{C}$ was taken as an indicator for the iron dissolution within the structure (Figure 5). Relations between the lattice parameters $a$ and $b$ of mullites sintered from kaolin samples and from FA and FA/K mixtures at 1000 and $1300{ }^{\circ} \mathrm{C}$ (Figure 5a) are performed with the parameters $a$ and $b$ in mullites without/with substitution Fe reported in the literature [40] (Figure 5b). FA (containing $\mathrm{Fe}_{2} \mathrm{O}_{3}$ about 7 mass\%, Table 1) was sintered to mullites with the probable Fe substitution in the mullite presented on the samples FA-1000 and FA-1300 (Figure 5a). Kaolins K1, K2 and K3 (containing $\mathrm{Fe}_{2} \mathrm{O}_{3}$ about 1 mass\%, (Table 1) transform at $1000{ }^{\circ} \mathrm{C}$ to the crystalline mullites in K1-1000, K2-1000 and K3-1000 (Figure 2a, Table 2). Their lattice parameters $b$ are large and outside the ranges of mullites (Figure $5 b$ ). Intensity of mullite peaks in FA/K1-1000 and FA/K3-1000 is slightly reduced (Figure 3a) and lattice parameters are shorter in comparison with mullite in FA-1000 (Figure 5a).

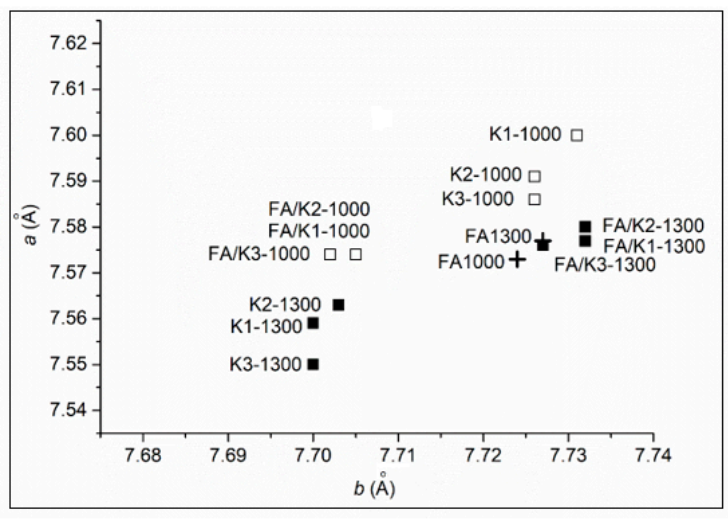

(a)

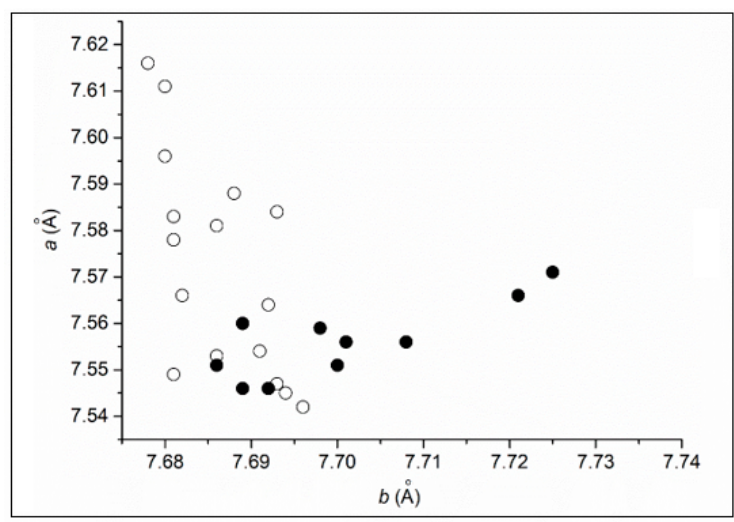

(b)

Figure 5. Structural relation of mullite lattice parameters $a$ and $b$ of: (a) sintered in this work samples and (b) reported in the literature [40] without iron substitution $(\bigcirc)$ and with substitution $\mathrm{Fe}(\bullet)$. 
Secondary mullites of K1-1300, K2-1300 and K3-1300 samples produced XRD patterns very similar with mullite of FA-1300 (Figure $2 \mathrm{~b}$ ), while parameters $a$ and $b$ are about $0.03 \AA$ smaller, probably due to the low Fe substitution (Figure 5). Parameter $b$ of mullites FA/K1-1300, FA/K2-1300 and FA/K3-1300 is larger by about $0.03 \AA$, in comparison with those parameters in mullites FA/K1-1000, FA/K2-1000 and FA/K3-1000 ${ }^{\circ} \mathrm{C}$, and is similar with parameters reported for the mullites with the substitution of $\mathrm{Fe}$ in the structure reported by [40] (Figure 5b). Moreover, $b$ parameter in mullite structures of FA/K1-1300 and FA/K2-1300 is about $0.01 \AA$ larger in comparison with $b$ parameter in mullite structures of FA/K3-1300 and FA-1300.

\subsection{Effect of Kaolins on Porosity, Shrinkage, and Compressive Strength}

Porosity of samples was formed by pores in the unimodal, bimodal and multimodal pores size distribution at annealed temperatures 1000, 1100, 1200 and $1300{ }^{\circ} \mathrm{C}$ (Figure 6) as follows:

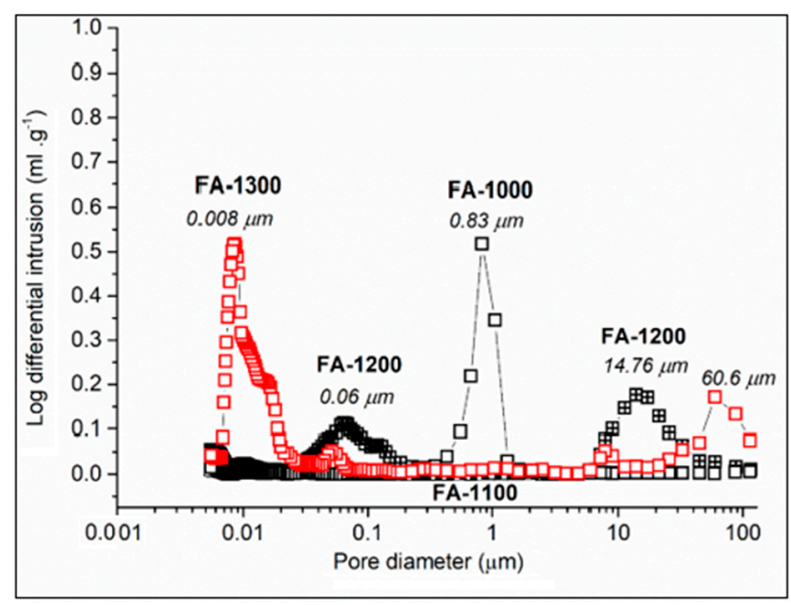

(a)

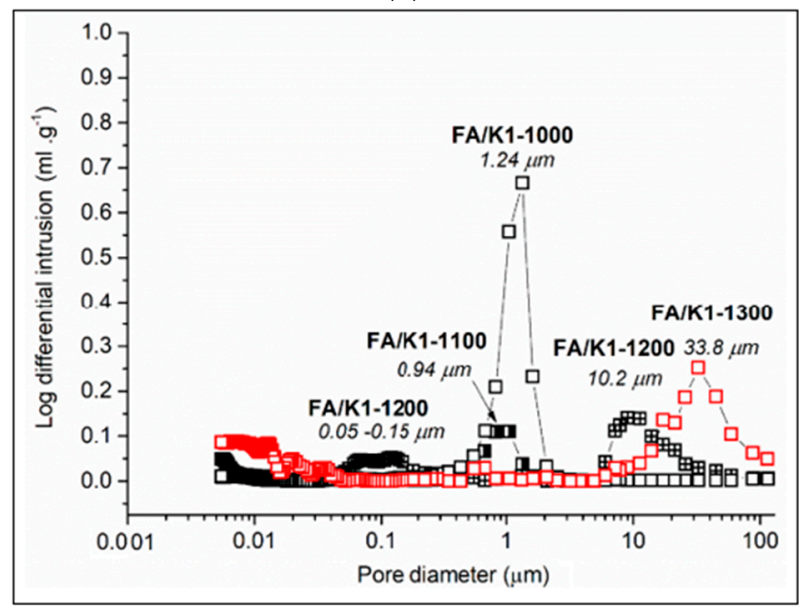

(c)

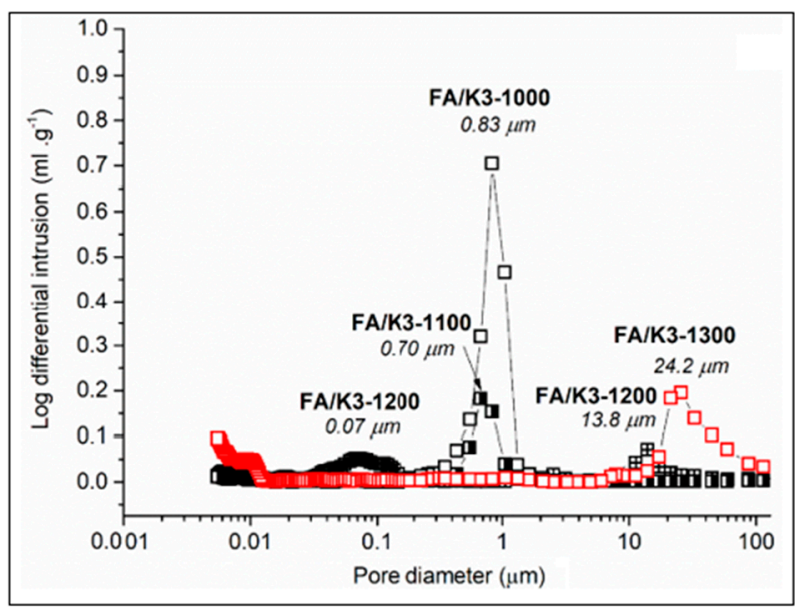

(b)

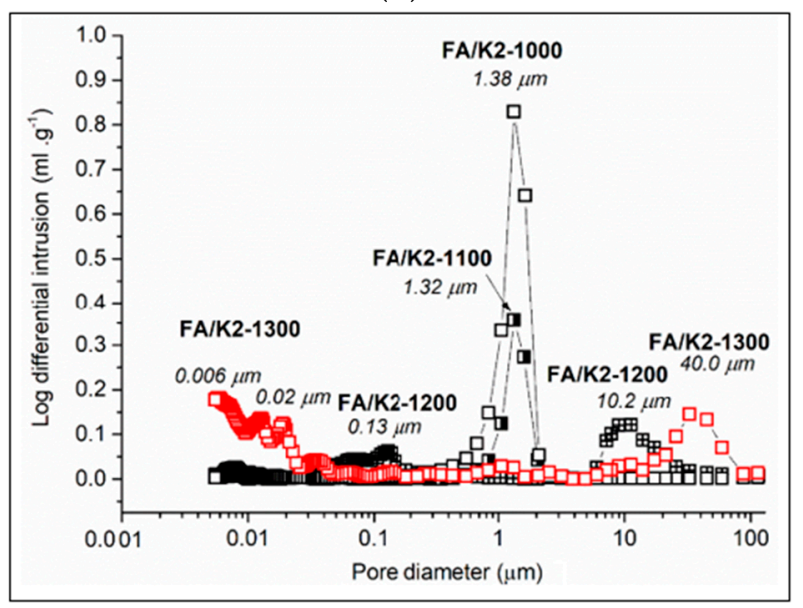

(d)

Figure 6. Pore size distribution at 1000, 1100, 1200 and $1300{ }^{\circ} \mathrm{C}$ in: (a) FA, (b) FA/K3, (c) FA/K1 and (d) FA/K2.

The samples annealed at $1000{ }^{\circ} \mathrm{C}$ show: (I) unimodal pore size distribution with the pores size region at about $0.83 \mu \mathrm{m}$ in FA-1000 and FA/K3-1000; $1.24 \mu \mathrm{m}$ in FA/K1-1000 and $1.38 \mu \mathrm{m}$ in FA/K2-1000.

The samples annealed at $1100{ }^{\circ} \mathrm{C}$ show: (I) unimodal pore size distribution in the region with zero pores in FA-1100; $0.70 \mu \mathrm{m}$ in FA/K3-1100; $0.94 \mu \mathrm{m}$ in FA/K1-1100 and $1.32 \mu \mathrm{m}$ in FA/K2-1100. 
The samples annealed at $1200{ }^{\circ} \mathrm{C}$ show: (II) bimodal pore size distribution with the pores size in the two regions: 0.06 and $14.76 \mu \mathrm{m}$ in FA-1200; 0.07 and $13.8 \mu \mathrm{m}$ in FA/K31200; and (III) multimodal pore size distribution region from 0.05 to $0.15 \mu \mathrm{m}$ and the region of $10.2 \mu \mathrm{m}$ in FA/K1-1200; from 0.006 to $0.13 \mu \mathrm{m}$ and the region of $10.2 \mu \mathrm{m}$ in FA/K2-1200.

The samples annealed at $1300{ }^{\circ} \mathrm{C}$ show: (II) bimodal pore size distribution with the pores size in the two regions: 0.008 and $60.6 \mu \mathrm{m}$ in FA-1300; 0.01 and $24.8 \mu \mathrm{m}$ in FA/K31300; and (III) multimodal pore size distribution region pores smaller than 0.05 and the pores size of $33.8 \mu \mathrm{m}$ in FA/K1-1300; a more pronounced multimodal pore size distribution in FA/K2-1300 from the region 0.006 to $0.13 \mu \mathrm{m}$ to the region of $40.0 \mu \mathrm{m}$.

The sintering FA and kaolin aids shifted the pore sizes toward smaller values. This phenomenon may be ascribed to the generation of more liquid phase during the sintering processes when kaolins were added.

The shrinkage at the temperatures of 1000,1100 , and $1200{ }^{\circ} \mathrm{C}$ (Figure 7) can also be accompanied by the formation of crystalline phases during sintering. The thermal shrinkage at $1100^{\circ}$ (Figure 7a) and porosity (Figure 7b), and bulk density at $1200-1300{ }^{\circ} \mathrm{C}$ (Figure 7c) were attributed to a mullitization-crystal-growth induced volume expansion [41].

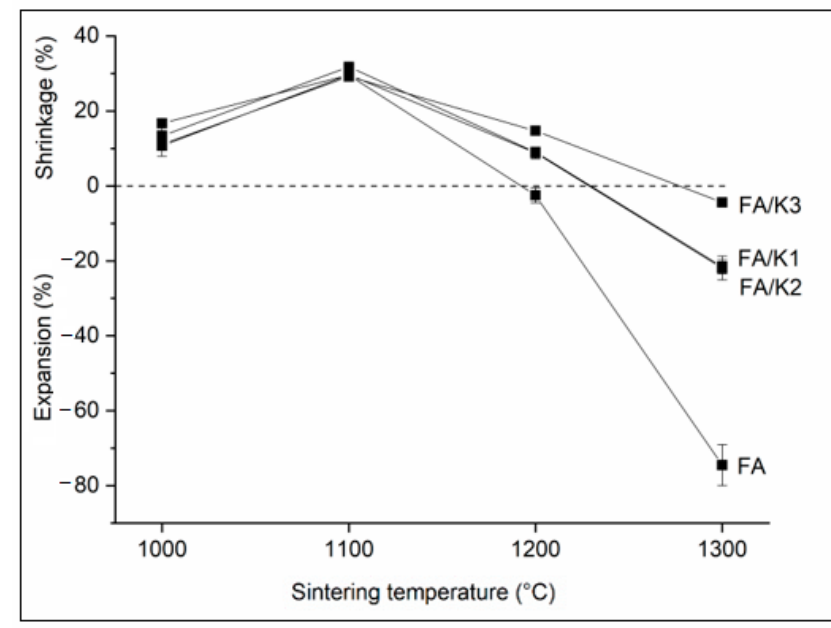

(a)

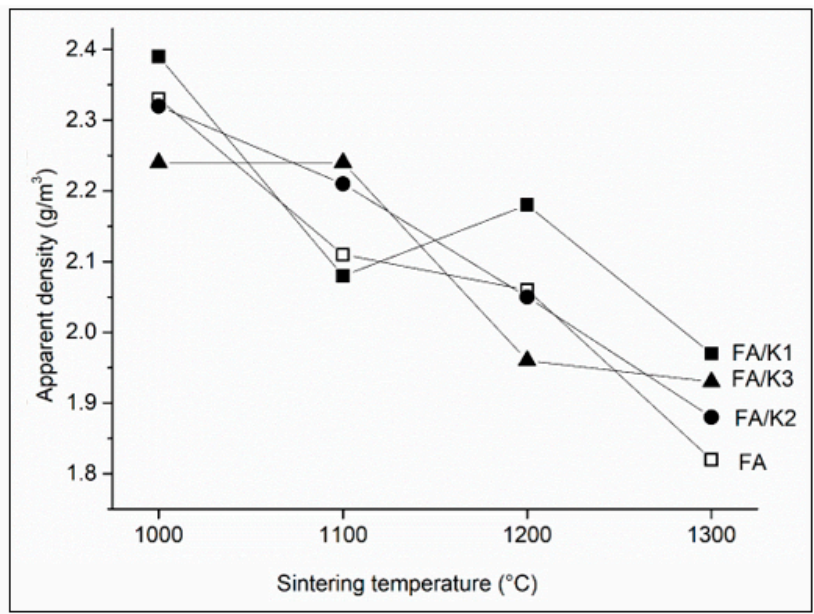

(c)

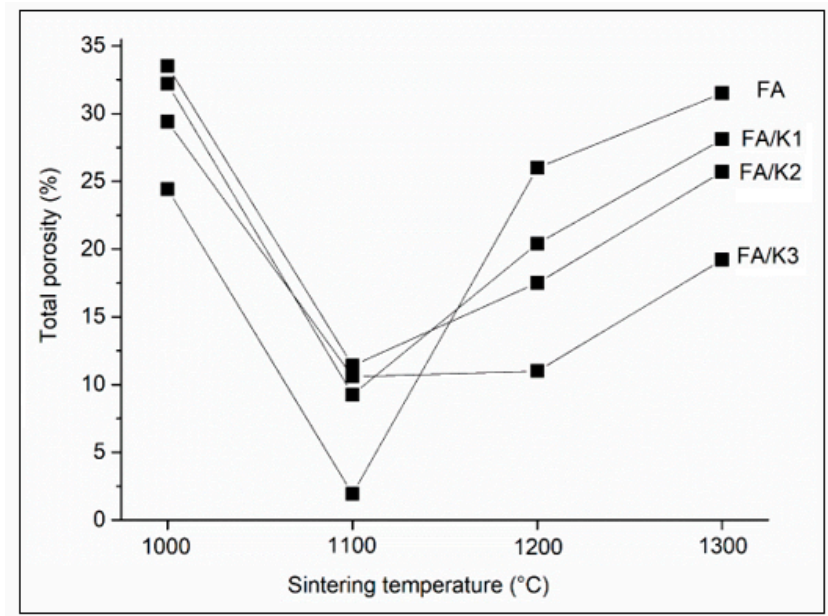

(b)

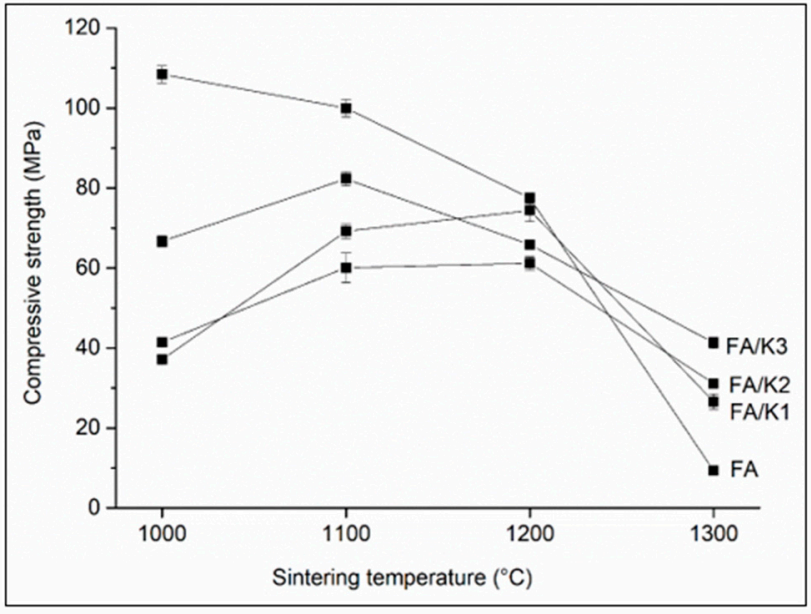

(d)

Figure 7. Post-sintering properties of ceramic samples FA and FA/K: (a) basal shrinkage, (b) porosity, (c) apparent density and (d) compressive strength.

According to the literature, the process of vitrification started at sintering temperatures between 1050 and $1100{ }^{\circ} \mathrm{C}$ and the alkali metal oxides and alkaline earth metal oxides supported the emergence of secondary mullite at the lower temperature [42]. 
Average value of shrinkage $B S=30.0 \pm 1.0 \%$ calculated for post-sintered cubes at $1100{ }^{\circ} \mathrm{C}$ (Figure $7 \mathrm{a}$, Table 4 ) corresponds to the porosity $1.9 \%$ in FA-1100, 9.3 and $10.6 \%$ in FA/K1-1100 and FA/K3-1100, respectively, and 16.4\% in FA/K2-1100 (Figure 7b, Table 4). At $1200{ }^{\circ} \mathrm{C}$ expansion in FA-1200 while shrinkage in FA/K1-1200 (9.0 $\left.\pm 1.2 \%\right)$, FA/K2$1200(8.8 \pm 1.5 \%)$, and FA/K3-1200 (14.7 $\pm 1.1 \%)$ (Figure 7a) correspond disproportionately to values of porosity (Figure $7 \mathrm{~b}$, Table 4 ) and proportionately to the compressive strength (Figure $7 \mathrm{~d}$, Table 4). At $1300{ }^{\circ} \mathrm{C}$, samples expanded, apparent porosity increased and compressive strength decreases to a minimum in FA- 1300 and up to $50 \%$ less in FA/K11300, FA/K2-1300, and FA/K3-1300 than the value measured at annealed $1200{ }^{\circ} \mathrm{C}$ samples.

Microstructure of ceramic samples at sintering temperatures can be characterized by the porosity and apparent density in the relation with the compressive strength (Figure 8). Ceramic samples at sintering temperatures $1100{ }^{\circ} \mathrm{C}$ showed minimum porosity (Figure $7 \mathrm{~b}$ ) at high density (Figure 7c) and exhibited compressive strength higher than $50 \mathrm{MPa}$ (Figure 8). FA-1100 achieved a highest compressive strength of $100.1 \mathrm{MPa}$ at a porosity of $1.9 \%$ and density of $2.11 \mathrm{~g} / \mathrm{cm}^{3}$ (Table 4 ). However, FA-1300 reached only the smallest values of $9.3 \mathrm{MPa}$ at a porosity $29.2 \%$ and density of $1.82 \mathrm{~g} / \mathrm{cm}^{3}$ (Figure $8 \mathrm{a}$, Table 4). The FAK3-1100 exhibited good compressive strength of $87.6 \mathrm{MPa}$ at a porosity of $10.6 \%$ (Figure $8 \mathrm{a}$ ) and density of $2.24 \mathrm{~g} / \mathrm{cm}^{3}$ (Figure $8 \mathrm{~b}$ ) (Table 4). FAK3-1300 developed resistance to the twice compressive strength of $41.3 \mathrm{MPa}$ at a porosity of $19.2 \%$ (Figure $8 \mathrm{a}$ ) and density of $1.93 \mathrm{~g} / \mathrm{cm}^{3}$ (Figure 8b, Table 4). The other two samples FAK1-1100 and FAK2-1100 exhibited lower compressive strength of $65.2 \mathrm{MPa}$ and $60.1 \mathrm{MPa}$, respectively, which was further lowered on the FAK1-1300 and FAK2-1300 samples to $26.6 \mathrm{MPa}$ and 31.1 $\mathrm{MPa}$, respectively.

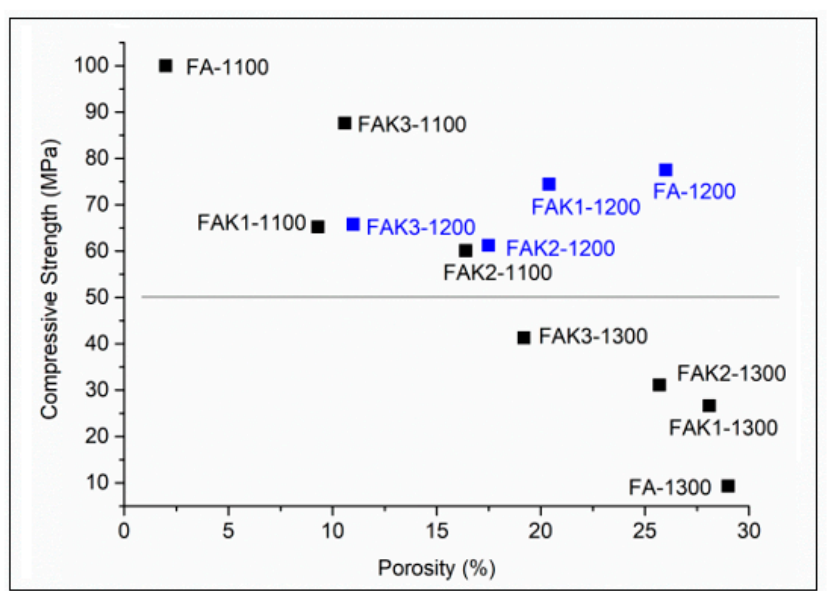

(a)

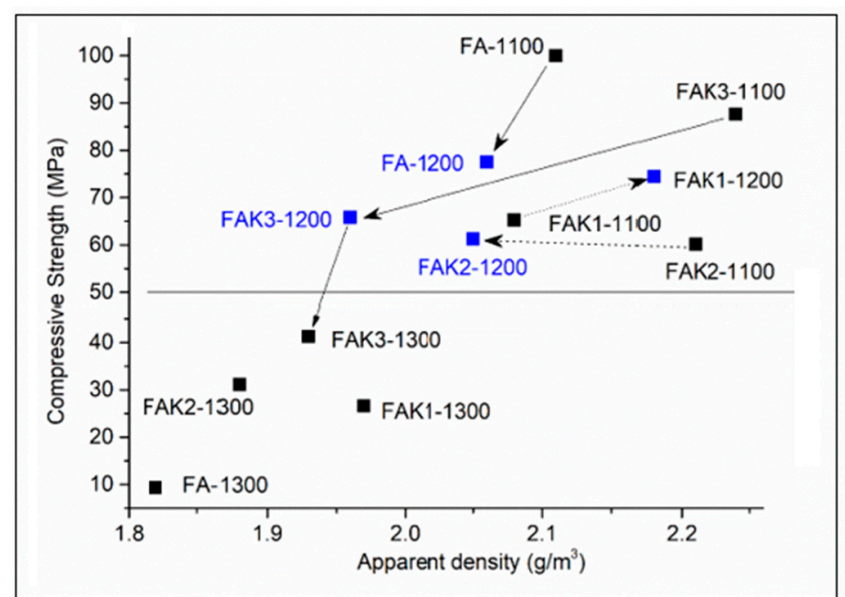

(b)

Figure 8. Compressive strength related to the porosity (a) and apparent density (b).

The glassy phase at $1100{ }^{\circ} \mathrm{C}$, resulting from the transformation of kaolinite and impurities such as $\mathrm{K}_{2} \mathrm{O}$ can influence the reactions and growth of mullite grains [43].

Samples sintered at $1300{ }^{\circ} \mathrm{C}$ in comparison to their samples sintered at 1100 and $1200{ }^{\circ} \mathrm{C}$ showed volume expansion, higher porosity and reduced bulk density (Table 4). In the literature, this phenomenon was explained on the basis of a detailed study of the sintering process [44]. The liquid phase generates at sintering temperature a certain value of capillary pressure at the contact points of the particles and binds the fine granules together, causing an increase in shrinkage. The gas in the closed pores exerts pressure on the pore walls, which is unfavorable for the densification of the sample. These closed pores expand as the pressure increases with the sintering temperature. When the sintering temperature exceeded a certain temperature $\left(1300^{\circ} \mathrm{C}\right)$ the increased content of liquid phase and released gases from decomposition reactions increase the apparent porosity at the expense of the bulk density decreased. 


\section{Conclusions}

The ceramics were prepared from the FA, three raw kaolins, and FA-kaolin additive $10 \%$ by mass by annealing at temperatures of 1000,11001200 and $1300{ }^{\circ} \mathrm{C}$.

Kaolin samples contained kaolinite from $85.5 \%$ to $77 \%$ by mass, quartz, muscovite and $\mathrm{K}$ - and $\mathrm{K}$,Na-orthoclase. Kaolins containing small amount of $\mathrm{Fe}_{2} \mathrm{O}_{3}$ (about 1 mass\%) and $\mathrm{Na}, \mathrm{K}$ feldspars were sintered at $1300{ }^{\circ} \mathrm{C}$ to the mullite with the negligible substitution of $\mathrm{Fe}^{3+}$ for $\mathrm{Al}^{3+}$ in the structure. This phenomenon in mullite structures crystallizing in ceramics annealed from mixtures of these kaolins with fly ash was verified on the literary data.

Ceramics annealed at temperatures 1000 and $1100{ }^{\circ} \mathrm{C}$ showed unimodal pores size distribution and porosity slightly higher, supported by the kaolins containing $\mathrm{Na}$, K-feldspars. Annealing at temperatures $1200{ }^{\circ} \mathrm{C}$ and $1300{ }^{\circ} \mathrm{C}$ produced in ceramics bimodal pore size distribution in FA and FA/K3 (containing K-feldspar) in comparison with multimodal pore size distribution in FA/K1 and FA/K2 (containing Na,K-feldspar).

Ceramic samples produced from kaolins additive containing $\mathrm{Na}, \mathrm{K}$ feldspars in comparison with kaolins additive containing K-feldspar showed lower shrinkage values corresponding to the compressive strength.

Microstructure of ceramic samples at sintering temperatures was characterized by the porosity and apparent density in the relation with the compressive strength. Ceramic samples at sintering temperature $1100{ }^{\circ} \mathrm{C}$ showed minimum porosity, high density and exhibited compressive strength higher than $50 \mathrm{MPa}$. At sintering temperature $1300{ }^{\circ} \mathrm{C}$ porosity increases at the expense of density and resistance to the compressive strength. The best structural and mechanical characteristics were found for FAK3 sample, supported by the high content of kaolinite and orthoclase in kaolin $\mathrm{K} 3$ additive. The FAK3 annealed at- $1100{ }^{\circ} \mathrm{C}$ exhibited good compressive strength of $87.6 \mathrm{MPa}$ at a porosity of $10.6 \%$ and density of $2.24 \mathrm{~g} / \mathrm{cm}^{3}$ and the best properties of FAK3-1300: the compressive strength of $41.3 \mathrm{MPa}$ at a porosity of $19.2 \%$ and density of $1.93 \mathrm{~g} / \mathrm{cm}^{3}$.

Author Contributions: Conceptualization, M.V.; methodology, M.V., V.B. and J.V.; validation, V.B. and J.V.; formal analysis, V.B.; investigation, M.V. and V.B.; resources, J.V.; data curation, M.V. and V.B.; writing-M.V.; writing-review and editing, M.V.; visualization, M.V.; supervision, J.V.; project administration, J.V.; funding acquisition, J.V. All authors have read and agreed to the published version of the manuscript.

Funding: The work was supported by the ERDF “Institute of Environmental Technology-Excellent Research" (No. CZ.02.1.01/0.0/0.0/16_019/0000853) and the Large Research Infrastructure ENREGAT (project No. LM2018098).

Data Availability Statement: All data supporting reported results are performed in this paper.

Acknowledgments: The authors would like to thank Alexandr Martaus for XRF and XRD data, Silvie Vallová for DTA/TG analysis, and Soňa Študentová for porosimetry measurement.

Conflicts of Interest: The authors declare no conflict of interest. The funders had no role in the design of the study; in the collection, analyses, or interpretation of data; in the writing of the manuscript, or in the decision to publish the results.

\section{References}

1. Zacco, A.; Borgese, L.; Gianoncelli, A.; Struis, R.P.W.J.; Depero, L.E.; Bontempi, E. Review of fly ash inertisation treatments and recycling. Environ. Chem. Lett. 2014, 12, 153-175. [CrossRef]

2. Hossain, S.S.; Roy, P. Sustainable ceramics derived from solid wastes: A review. J. Asian Ceram. Soc. 2020, 8, 984-1009. [CrossRef]

3. Kamseu, E.; Leonelli, C.; Boccaccini, D.N.; Veronesi, P.; Miselli, P.; Pellacani, G.; Melo, U.C. Characterisation of porcelain compositions using two China clays from Cameroon. Ceram. Int. 2007, 33, 851-857. [CrossRef]

4. Dana, K.; Das, S.; Das, S.K. Effect of substitution of fly ash for quartz in triaxial kaolin-quartz-feldspar system. J. Eur. Ceram. Soc. 2004, 24, 3169-3175. [CrossRef]

5. Pal, M.; Das, S.K. Phase and microstructural evolution in quartz-free porcelain tile compositions. J. Australas. Ceram. Soc. 2018, 54, 109-117. [CrossRef] 
6. Luo, Y.; Zheng, S.; Ma, S.; Liu, C.; Wang, X. Ceramic tiles derived from coal fly ash: Preparation and mechanical characterization. Ceram. Int. 2017, 43, 11953-11966. [CrossRef]

7. Kumar, S.; Singh, K.K.; Ramachandrarao, P. Effects of fly ash additions on the mechanical and other properties of porcelainised stoneware tiles. J. Mater. Sci. 2001, 36, 5917-5922. [CrossRef]

8. Olgun, A.; Erdogan, Y.; Ayhan, Y.; Zeybek, B. Development of ceramic tiles from coal fly ash and tincal ore waste. Ceram. Int. 2005, 31, 153-158. [CrossRef]

9. Kockal, N.U. Utilisation of different types of coal fly ash in the production of ceramic tiles. Bol. Soc. Esp. Ceram. V 2012, 51, 297-304. [CrossRef]

10. Aineto, M.; Acosta, A.; Iglesias, I. The role of a coal gasification fly ash as clay additive in building ceramic. J. Eur. Ceram. Soc. 2006, 26, 3783-3787. [CrossRef]

11. Luo, Y.; Ma, S.; Zheng, S.; Liu, C.; Han, D.; Wang, X. Mullite-based ceramic tiles produced solely from high-alumina fly ash: Preparation and sintering mechanism. J. Alloys Compd. 2018, 732, 828-837. [CrossRef]

12. Agarwal, A.; Samanta, A.; Nandi, B.K.; Mandal, A. Synthesis, characterization and performance studies of kaolin-fly ash-based membranes for microfiltration of oily waste water. J. Pet. Sci. Eng. 2020, 194, 107475. [CrossRef]

13. Chen, S.; Cai, W.H.; Wu, J.M.; Ma, Y.X.; Li, C.H.; Shi, Y.S.; Yan, C.Z.; Wang, Y.J.; Zhang, H.X. Porous mullite ceramics with a fully closed-cell structure fabricated by direct coagulation casting using fly ash hollow spheres/kaolin suspension. Ceram. Int. 2020, 46, 17508-17513. [CrossRef]

14. Schneider, H.; Komarneni, S. (Eds.) Mullite; Wiley VCH: Weinheim, Germany, 2005.

15. Brindley, G.W.; Nakahira, M. A new concept of the transformation sequence of kaolinite to mullite. Nature 1958, 181, 1333-1334. [CrossRef]

16. Castelein, O.; Soulestin, B.; Bonnet, J.P.; Blanchart, P. The influence of heating rate on the thermal behaviour and mullite formation from a kaolin raw material. Ceram. Int. 2001, 27, 517-522. [CrossRef]

17. Moreno-Tovar, R.; Pérez-Moreno, F.; Arenas-Flores, A.; Romero-Guerrero, L.M. Thermal behavior, chemical, mineralogical and optical characterization of clays (kaolin) for industrial use as refractory material. Adv. Mater. Res. 2014, 976, 174-178. [CrossRef]

18. Takei, T.; Kameshima, Y.; Yasumori, A.; Okada, K. Crystallization kinetics of mullite in alumina-silica fibers. J. Am. Ceram. Soc. 1999, 82, 2876-2880. [CrossRef]

19. Chakraborty, A.K. Structural parameters of mullite formed during deating of diphasic mullite gels. J. Am. Ceram. Soc. 2005, 88, 2424-2428. [CrossRef]

20. Chakravorty, A.K.; Ghosh, D.K. Kaolinite-mullite reaction series: The development and significance of a binary aluminosilicate phase. J. Am. Ceram. Soc. 1991, 74, 1401-1406. [CrossRef]

21. Chen, Y.F.; Chang, Y.H.; Wang, M.C.; Hon, M.H. Effects of $\mathrm{Al}_{2} \mathrm{O}_{3}$ addition on the phases, flow characteristics and morphology of the porous kaolin ceramics. Mater. Sci. Eng. A 2004, 373, 221-228. [CrossRef]

22. Ban, T.; Okada, K. Structure refinement of mullite by the Rietveld method and a new method for estimation of chemical composition. J. Am. Ceram. Soc. 1992, 75, 227-230. [CrossRef]

23. Schneider, H.; Rager, H. Iron incorporation in mullite. Ceram. Int. 1986, 12, 117-125. [CrossRef]

24. Schroeder, P.A.; Pruett, R.J.; Melear, N.D. Crystal-chemical changes in an oxidative weathering front in a Georgia kaolin deposit. Clays Clay Miner. 2004, 52, 211-220. [CrossRef]

25. Yamuna, A.; Devanarayanan, S.; Lalithambika, M. Phase-pure mullite from kaolinite. J. Am. Ceram. Soc. 2002, 85, 1409-1413. [CrossRef]

26. Aras, A. The change of phase composition in kaolinite and illite-rich clay-based ceramic bodies. Appl. Clay Sci. 2004, 24, 257-269. [CrossRef]

27. Li, X.; Zhi, L.; Shi, W.; Kong, L.; Bai, J.; Yu, J.; Reinmöller, M.; Guhl, S.; Meyer, B.; Li, W. Effect of $\mathrm{K}_{2} \mathrm{O} / \mathrm{Na}_{2} \mathrm{O}$ on fusion behavior of coal ash with high silicon and aluminum level. Fuel 2020, 265, 116964. [CrossRef]

28. Lecomte, G.L.; Bonnet, J.P.; Blanchart, P. A study of the influence of muscovite on the thermal transformations of kaolinite from room temperature up to $1100{ }^{\circ} \mathrm{C}$. J. Mater. Sci. 2007, 42, 8745-8752. [CrossRef]

29. Hou, Y.; Cui, B.; Liu, L.; Liu, Q. Effect of the different additives on the fabrication of porous kaolin- based mullite ceramics. Ceram. Int. 2016, 42, 17254-17258. [CrossRef]

30. Chmielova, M.; Weiss, Z. Determination of structural disorder degree using an XRD profile fitting procedure. Application to Czech kaolins. Appl. Clay Sci. 2002, 22, 65-74. [CrossRef]

31. Valášková, M.; Klika, Z.; Novosad, B.; Smetana, B. Crystallization and quantification of crystalline and non-crystalline phases in kaolin-based cordierites. Materials 2019, 12, 3104. [CrossRef]

32. ASTM C618-92a. Standard Specification for Coal Fly Ash and Raw or Calcined Natural Pozzolan for Use as a Mineral in Concrete; ASTM International: West Conshohocken, PA, USA, 2019.

33. Chung, F.H. Quantitative interpretation of X-ray diffraction patterns. I. Matrix-flushing method of quantitative multicomponent analysis. J. Appl. Cryst. 1974, 7, 519-525. [CrossRef]

34. Wei, L.; Yang, J.C.; Ko, K.W. Evidence for a new mechanism of $\mathrm{Fe}_{2} \mathrm{O}_{3}$ decomposition in lightweight aggregate formation. Environ. Chem. Lett. 2012, 10, 41-47. [CrossRef]

35. Wang, Y.; Xiang, Y.; Wang, D.; Dong, C.; Yang, Y.; Xiao, X.; Lu, Q.; Zhao, Y. Effect of sodium oxides in ash composition on ash fusibility. Energy Fuels 2016, 30, 1437-1444. [CrossRef] 
36. Tabit, K.; Hajjou, H.; Waqif, M.; Saâdi, L. Effect of $\mathrm{CaO} / \mathrm{SiO} 2$ ratio on phase transformation and properties of anorthite-based ceramics from coal fly ash and steel slag. Ceram. Int. 2020, 46, 7550-7558. [CrossRef]

37. Muir, I.D.; Smith, J.V. Crystallisation of feldspars in larvikites. Zeit. Krist. 1955, 107, 182-195. [CrossRef]

38. Huffman, G.P.; Huggins, F.E.; Dunmyre, G.R. Investigation of the high temperature behaviour of coal ash in reducing and oxidising atmospheres. Fuel 1981, 60, 585-597. [CrossRef]

39. Hsu, C.T.; Chou, C.J.; Huang, T.S.; Hung, P.M.; Chen, C.N. The effect of firing shrinkage ratio of ceramics on thickness. J. Interdiscipl. Math. 2017, 20, 937-950. [CrossRef]

40. Dong, Y.; Feng, X.; Feng, X.; Ding, Y.; Liu, X.; Meng, G. Preparation of low-cost mullite ceramics from natural bauxite and industrial waste fly ash. J. Alloys Compd. 2008, 460, 599-606. [CrossRef]

41. Jordan, M.; Montero, M.; Meseguer, S.; Sanfeliu, T. Influence of firing temperature and mineralogical composition on bending strength and porosity of ceramic tile bodies. Appl. Clay Sci. 2008, 422, 66-271. [CrossRef]

42. Chen, G.; Ge, X.; Wang, Y.; Xing, W.; Guo, Y. Design and preparation of high permeability porous mullite support for membranes by in-situ reaction. Ceram. Int. 2015, 41, 8282-8287. [CrossRef]

43. Kobayashi, Y.; Ohira, O.; Ohashi, Y.; Kato, E. Effect of firing temperature on bending strength of porcelains for tableware. J. Am. Ceram. Soc. 2010, 75, 1801-1806. [CrossRef]

44. Wang, H.; Yhu, M.; Sun, Z.; Ji, R.; Liu, L.; Wang, X. Synthesis of a ceramic tile base based on high-alumina fly ash. Constr. Build. Mater. 2017, 155, 930-938. [CrossRef] 